To Maega | Jurnal Pengabdian Masyarakat

Februari-2022, Vol.5, No.1, hal, 9-23

$\operatorname{ISSN}(P): 2622-6332 ; \operatorname{ISSN}(E): 2622-6340$

http://www.ojs.unanda.ac.id/index.php/tomaega

\title{
Sosialisasi Kebijakan Transformasi dan Revitalisasi Balai Pengembangan dan Penjaminan Mutu Pendidikan Vokasi
}

\author{
Abdul Rahman 1*, Winda Dwi Astuti Zebua ${ }^{2}$, Andrean Alan Kusuma ${ }^{3}$ \\ ${ }^{*}$ Program Studi Ilmu Administrasi Publik, Fakultas IImu Sosial dan Ilmu Politik, Universitas \\ Muhammadiyah Jakarta \\ 2 Program Studi IImu Komunikasi, Fakultas IImu Sosial dan IImu Politik, Universitas \\ Muhammadiyah Jakarta \\ ${ }^{3}$ Program Studi IImu Administrasi Publik, Fakultas IImu Sosial dan Ilmu Politik, Universitas \\ Muhammadiyah Jakarta \\ *Correspondent Email: abdul.rahman27316@gmail.com
}

Article History:

Received: 15-10-2021; Received in Revised: 05-11-2021; Accepted: 15-11-2021

DOI: http://dx.doi.org/10.35914/tomaega.v5i1.918

\begin{abstract}
Abstrak
Balai Pengembangan Penjaminan Mutu Pendidikan Vokasi (BPPMPV) merupakan Unit Pelaksana Teknis (UPT) di bawah Direktorat Jenderal Pendidikan Vokasi. Pembetukannya didasarkan pada Peraturan Menteri Pendidikan dan Kebudayaan No. 26 Tahun 2020 tentang Organisasi dan Tata Kerja Unit Pelaksana Teknis Kementerian Pendidikan dan Kebudayaan. Kebijakan tersebut relatif baru, sehingga diperlukan sosialisasi yang massif kepada pelbagai entitas pendidikan vokasi, termasuk BPPMPV. Selain itu, ruang lingkupnya relatif terbatas hanya pada aspek penjaminan mutu, sehingga dilengkapi dengan kebijakan 4 aspek revitalisasi BPPMPV oleh Direktur Jenderal Pendidikan Vokasi. Kegiatan pengabdian masyarakat ini bertujuan untuk meningkatkan pemahaman entitas BPPMPV terhadap 2 produk kebijakan tersebut. Metode yang digunakan ialah sosialisasi kepada entitas BPPMPV sebanyak 30 peserta dengan beberapa tahapan mulai dari persiapan, pelaksanaan, sampai dengan evaluasi. Hasil pengabdian masyarakat ini menunjukkan bahwa terdapat peningkatan pemahaman yang cukup signifikan dari 30 peserta sosialisasi, dengan total 19 peserta yang menjadi sangat memahami kebijakan pertama, dan sebanyak 21 peserta yang menjadi sangat memahami kebijakan yang kedua. Di sisi lain, tingkat kepuasan peserta terhadap pelaksanaan kegiatan juga tinggi, karena sebanyak $77 \%$ peserta puas terhadap pelaksanaan sosialisasi.
\end{abstract}

Kata Kunci: Kebijakan Transformasi, Kebijakan Revitalisasi, Balai Pengembangan Penjaminan Mutu Pendidikan Vokasi

\footnotetext{
Abstract

The Vocational Education Quality Assurance Development Center (BPPMPV) is a Technical Implementation Unit (UPT) under the Directorate General of Vocational Education. Its formation is based on the Regulation of the Minister of Education and Culture No. 26 of 2020 concerning the Organization and Work Procedure of the Technical Implementation Unit of the Ministry of Education and Culture. Due to the policy is relatively new, so that massive socialization is needed to various vocational education entities, including BPPMPV. In addition, its scope is relatively limited only to the aspect of quality assurance, so it is equipped with a policy of 4 aspects of BPPMPV revitalization by the Director General of Vocational Education. This community service activity aims to increase the understanding of the BPPMPV entity on the 2 policy products. The method 
used is socialization to the BPPMPV entity as many as 30 participants with several stages ranging from preparation, implementation, to evaluation. The results of this community service show that there was a significant increase in understanding from 30 participants in the socialization, with a total of 19 participants who became very understanding of the first policy, and as many as 21 participants who became very understanding of the second policy. On the other hand, the level of participant satisfaction with the implementation of the activities is also high. A total of $77 \%$ of participants expressed satisfaction with the implementation of the socialization.

Key Word: Transformation Policy, Revitalization Policy, Center for Quality Assurance Development for Vocational Education

\section{Pendahuluan}

Transformasi dan revitalisasi pendidikan merupakan upaya yang diperlukan untuk mengakselerasi tujuan pendidikan nasional sesuai dengan amanat Undangundang Nomor 20 Tahun 2003 tentang Sistem Pendidikan Nasional (Undangundang Nomor 20 Tahun 2003 Tentang Sistem Pendidikan Nasional, 2003) dan Peraturan Pemerintah Nomor 57 Tahun 2021 tentang Standar Nasional Pendidikan (Peraturan Pemerintah Republik Indonesia, 2021), baik di pendidikan akademik, maupun pendidikan vokasi. Pendidikan vokasi sendiri merupakan pendidikan yang melibatkan (selain pendidikan umum) berbagai keterampilan teknis dan pengetahuan yang berkaitan dengan pekerjaan di berbagai sektor kehidupan sosial dan ekonomi (Pilz, 2017).

Pendidikan vokasi seringkali bukan pilihan utama, namun pendidikan vokasi adalah proyek yang signifikan dan bernas untuk mengembangkan kapasitas yang diperlukan untuk memenuhi kebutuhan masyarakat, membantu individu menjadi kompeten dalam pekerjaan yang mereka pilih, dan mempertahankan kompetensi tersebut sepanjang masa kerja yang panjang, yang semuanya bergantung pada proses berpikir dan bertindak (Billett, 2016).

Saat ini kualifikasi vokasi perlu diperluas untuk menghadapi tantangan revolusi industri 4.0 (bahkan 5.0). Dunia kerja membutuhkan pendidikan vokasi yang mengutamakan pengembangan individu dan tujuan sosial seperti berpikir kritis, kemampuan beradaptasi, kreativitas, dan kewirausahaan sebagai prasyarat relevansi tenaga kerja (Hodge, Atkins, \& Simons, 2016; Jones, 2018; Agrawal \& Agrawal, 2017).

Kapabilitas SDM vokasi dalam beradaptasi dengan kecakapan global melalui pemenuhan kompetensi abad ke 21 menjadi sesuatu yang tidak bisa dielakkan. Secara umum keterampilan abad 21 atau yang dikenal dengan the 21 st century skills ini digambarkan menjadi 4C's skills yaitu terampil dalam hal berkomunikasi (communication), kreativitas (creativity), kolaborasi (collaboration) dan berfikir kritis (critical thinking) (Widodo \& Wardani, 2020).

Sejalan dengan keinginan untuk menyiapkan SDM Vokasi yang kuat untuk Indonesia, Kementerian Pendidikan, Kebudayaan, Riset, dan Teknologi sudah berupaya menginisiasi pembangunan link and match pendidikan vokasi dengan menerapkan pendidikan sistem ganda sejak tahun 2007. 
Penyelarasan kurikulum dengan industri dan dunia usaha mulai dilakukan dan diimplementasikan dengan berkolaborasi dengan KADIN untuk mengajak dunia usaha dan industri menerapkan pendidikan sistem ganda. Seiring dengan perjalanan waktu dan dinamika kebijakan, pada Tahun 2007 terjadi perubahan organisasi, dimana terbentuk Pusat Pengembangan dan Pemberdayaan Pendidik dan Tenaga Kependidikan (PPPPTK) di bawah supervisi Direktorat Jenderal Peningkatan Mutu Pendidik dan Tenaga Kependidikan (PMPTK).

Kementerian Pendidikan dan Kebudayaan kemudian mentransformasi PPPPTK baik secara kelembagaan maupun substansi dengan menerbitkan kebijakan Peraturan Menteri Pendidikan dan Kebudayaan No. 26 Tahun 2020 tentang Organisasi dan Tata Kerja Unit Pelaksana Teknis Kementerian Pendidikan dan Kebudayaan. Kebijakan tersebut termasuk kebijakan dalam bentuk keputusan yang dibuat oleh Negara, sebagai strategi untuk merealisasikan tujuan dari Negara (Nugroho, 2017).

Di dalam produk kebijakan tersebut, terdapat Unit Pelaksana Teknis (UPT) Balai Besar Pengembangan Penjaminan Mutu Pendidikan Vokasi (BBPPMPV) dan Balai Pengembangan Penjaminan Mutu Pendidikan Vokasi (BPPMPV) (Kemdikbud RI, 2020) seperti yang ditunjukkan pada gambar 3 di bawah ini:

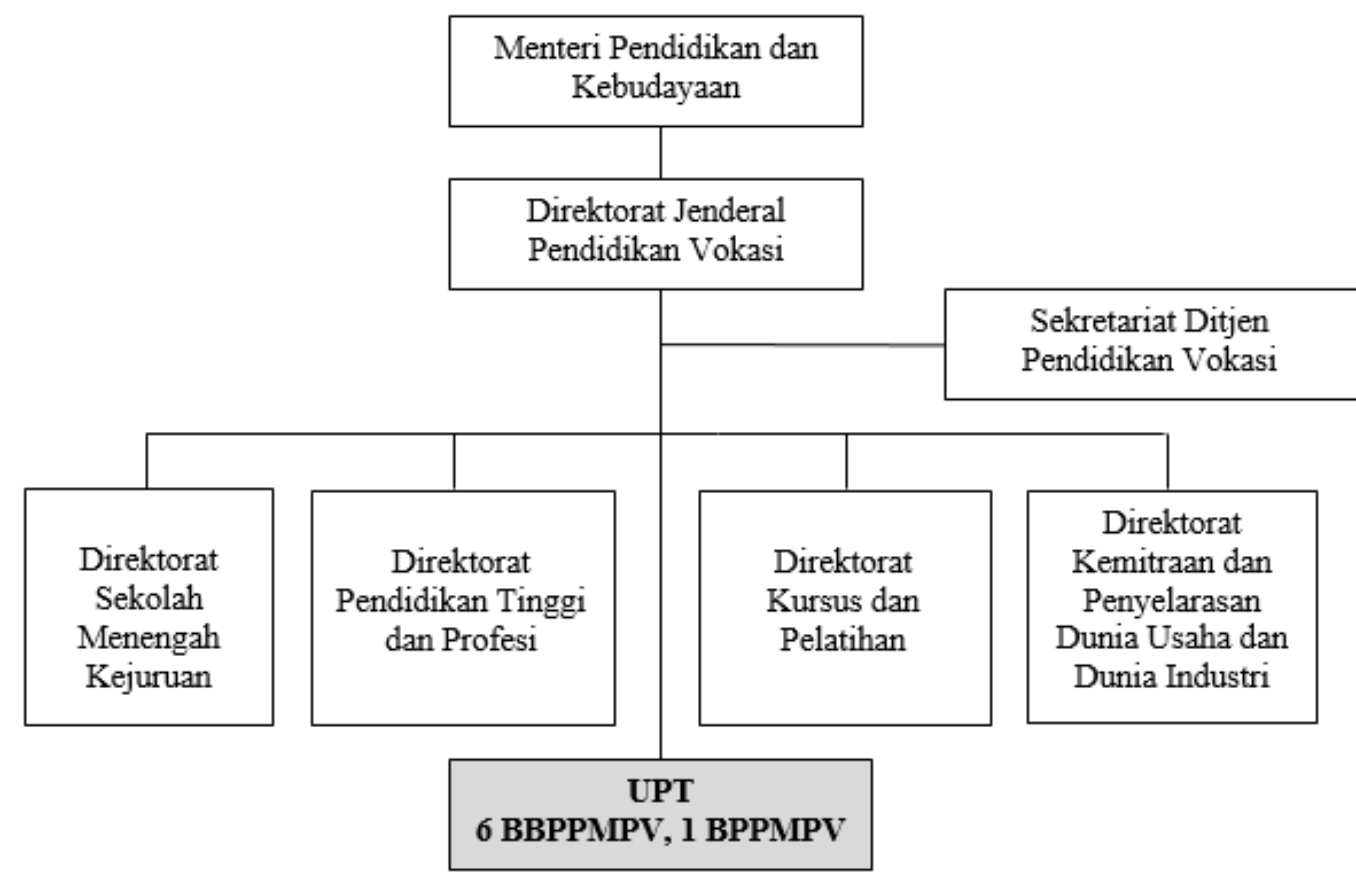

Gambar 1. Posisi BBPPMPV dan BPPMPV dalam Struktur Direktorat Jenderal Pendidikan Vokasi

Berdasarkan gambar struktur organisasi tersebut, kerangka kelembagaan PPPPTK direvitalisasi melalui diterbitkannya Permendikbud 26/2020. Dalam regulasi tersebut, nomenklatur PPPPTK diubah menjadi BBPPMPV dan BPPMPV. Terdapat 6 BBPPMPV dan 1 BPPMPV yang terdistribusi di seluruh wilayah 
[12] Abdul Rahman, dkk/To Maega: Jurnal Pengabdian Masyarakat, Vol.5; No.1; Februari, 2022

Indonesia, dengan bidang tugasnya masing-masing sebagaimana tertera pada tabel di bawah ini:

Tabel 1. Bidang Tugas dan Lokasi BBPPMPV dan BPPMPV

\begin{tabular}{|c|c|c|c|}
\hline No. & Nama & Bidang Tugas & Lokasi \\
\hline 1 & $\begin{array}{l}\text { Balai Besar Pengembangan } \\
\text { Penjaminan Mutu } \\
\text { Pendidikan Vokasi Seni dan } \\
\text { Budaya }\end{array}$ & $\begin{array}{l}\text { Seni dan Budaya pada } \\
\text { pendidikan dasar dan } \\
\text { menengah }\end{array}$ & $\begin{array}{l}\text { Ngaglik, } \\
\text { Kabupaten } \\
\text { Sleman, Daerah } \\
\text { Istimewa } \\
\text { Yogyakarta }\end{array}$ \\
\hline 2 & $\begin{array}{l}\text { Balai Besar Pengembangan } \\
\text { Penjaminan Mutu } \\
\text { Pendidikan Vokasi Bidang } \\
\text { Bangunan dan Listrik }\end{array}$ & $\begin{array}{l}\text { Bangunan dan Listrik } \\
\text { pada } \\
\text { Pendidikan menengah } \\
\text { kejuruan }\end{array}$ & $\begin{array}{l}\text { Helvetia, Kota } \\
\text { Medan, } \\
\text { Sumatera Utara }\end{array}$ \\
\hline 3 & $\begin{array}{l}\text { Balai Besar Pengembangan } \\
\text { Penjaminan Mutu } \\
\text { Pendidikan Vokasi Bisnis } \\
\text { dan Pariwisata }\end{array}$ & $\begin{array}{l}\text { Bisnis dan Pariwisata } \\
\text { pada } \\
\text { Pendidikan menengah } \\
\text { kejuruan }\end{array}$ & $\begin{array}{l}\text { Bojongsari, } \\
\text { Kota } \\
\text { Depok, Jawa } \\
\text { Barat }\end{array}$ \\
\hline 4 & $\begin{array}{l}\text { Balai Besar Pengembangan } \\
\text { Penjaminan Mutu } \\
\text { Pendidikan Vokasi } \\
\text { Pertanian }\end{array}$ & $\begin{array}{l}\text { Pertanian pada } \\
\text { pendidikan } \\
\text { menengah kejuruan }\end{array}$ & $\begin{array}{l}\text { Karang Tengah, } \\
\text { Kabupaten } \\
\text { Cianjur, Jawa } \\
\text { Barat }\end{array}$ \\
\hline 5 & $\begin{array}{l}\text { Balai Besar Pengembangan } \\
\text { Penjaminan Mutu } \\
\text { Pendidikan Vokasi Bidang } \\
\text { Mesin dan Teknik Industri }\end{array}$ & $\begin{array}{l}\text { Mesin dan Teknik } \\
\text { Industri pada } \\
\text { pendidikan } \\
\text { menengah kejuruan }\end{array}$ & $\begin{array}{l}\text { Cimahi Utara, } \\
\text { Kota Cimahi, } \\
\text { Jawa Barat }\end{array}$ \\
\hline 6 & $\begin{array}{l}\text { Balai Besar Pengembangan } \\
\text { Penjaminan Mutu } \\
\text { Pendidikan Vokasi Bidang } \\
\text { Otomotif dan Elektronika }\end{array}$ & $\begin{array}{l}\text { Otomotif dan } \\
\text { Elektronika pada } \\
\text { pendidikan } \\
\text { menengah kejuruan }\end{array}$ & $\begin{array}{l}\text { Blimbing, Kota } \\
\text { Malang, Jawa } \\
\text { Timur }\end{array}$ \\
\hline 7 & $\begin{array}{l}\text { Balai Pengembangan } \\
\text { Penjaminan Mutu } \\
\text { Pendidikan Vokasi Bidang } \\
\text { Kelautan, Perikanan, } \\
\text { Teknologi Informasi dan } \\
\text { Komunikasi }\end{array}$ & $\begin{array}{l}\text { Bidang Kelautan, } \\
\text { Perikanan, } \\
\text { Teknologi Informasi } \\
\text { dan } \\
\text { Komunikasi }\end{array}$ & $\begin{array}{l}\text { Pattalassang, } \\
\text { Kabupaten } \\
\text { Gowa, } \\
\text { Sulawesi } \\
\text { Selatan }\end{array}$ \\
\hline
\end{tabular}

Namun demikian, karena produk kebijakan tersebut relatif baru, maka belum sepenuhnya dipahami oleh pelbagai entitas vokasi, termasuk di BPPMPV Bidang Kelautan, Perikanan, Teknologi Informasi dan Komunikasi (KPTIK) Kabupaten Gowa, Sulawesi Selatan. Selain itu nomenklatur dan substansi proyeksi pembaruan kelembagaan dalam regulasi tersebut dirasakan belum cukup komprehensif untuk menjawab tantangan pemenuhan SDM pendidikan vokasi yang dituntut harus 
semakin berkualitas dan dapat menjembatani link and match dalam pelbagai aspek, antara pendidikan vokasi dengan dunia usaha dan dunia industri, terutama karena ruang lingkupnya yang relatif terbatas hanya pada aspek penjaminan mutu.

Oleh karena itu, selain tugas dan fungsi yang yang tertuang di dalam Permendikbud 26/2020 tersebut, Direktur Jenderal Pendidikan Vokasi juga menyampaikan beberapa aspek kebijakan revitalisasi yang harus diimplementasikan oleh seluruh entitas BBPPMPV dan BPPMPV. Aspek-aspek kebijakan revitalisasi tersebut bukan untuk mengganti klausul yang sudah termaktub dalam Permendikbud Nomor 26 Tahun 2020, tetapi justru untuk menyempurnakannya. Kebijakan revitalisasi dari Dirjen Pendidikan Vokasi tersebut, walaupun bukan dalam bentuk dokumen legal formal, namun termasuk dalam kategori kebijakan publik. Sebagaimana dinyatakan oleh Nakamura dan Smallwood, kebijakan publik merupakan serangkaian instruksi dari para pembuat keputusan kepada pelaksana kebijakan yang menjelaskan tujuan-tujuan dan caracara untuk mencapai tujuan (Tahir, 2014). Substansi dan esensi dari kedua produk kebijakan tersebut merupakan bagian yang tidak terpisahkan dari desain kebijakan yang akan menjadi determinan kesuksesan kebijakan (Rahman et al., 2021).

\section{Metode}

Kegiatan pengabdian masyarakat ini menggunakan metode sosialisasi. Berybe dkk menyatakan metode edukasi yang dilakukan mencakup sosialisasi dan penyuluhan sebagai sarana transfer ilmu pengetahuan dan pendidikan untuk pemberdayaan masyarakat (Dharta, Kusumaningrum, \& Chaerudin, 2021). Lokus kegiatan berada di BPPMPV Bidang KPTIK di Kabupaten Gowa, Sulawesi Selatan dan dilaksanakan pada 10-11 September. Sementara itu, kebijakan dimaksud ialah: 1) Peraturan Menteri Pendidikan dan Kebudayaan No. 26 Tahun 2020 tentang Organisasi dan Tata Kerja Unit Pelaksana Teknis Kementerian Pendidikan dan Kebudayaan; dan 2) Beberapa aspek revitalisasi strategis bagi BBPPMPV dan BPPMPV yang menjadi arahan Dirjen Pendidikan Vokasi, Kemendikbudristek. Tahapan-tahapannya ialah sebagai berikut:

1. Persiapan. Pada tahapan ini dimulai dari penyiapan persyaratan administrasi, yaitu surat izin, atau surat tugas pelaksanaan kegiatan. Setelah itu, dilanjutkan dengan komunikasi dan wawancara awal dengan Kepala BPPMPV Bidang KPTIK Gowa, Sulawesi Selatan dan beberapa staf terkait. Koordinasi dengan pihak-pihak tersebut dilakukan untuk merekonfirmasi maksud dan tujuan kegiatan, menginformasikan materi sosialisasi, dan mematangkan konsep teknis kegiatan. 


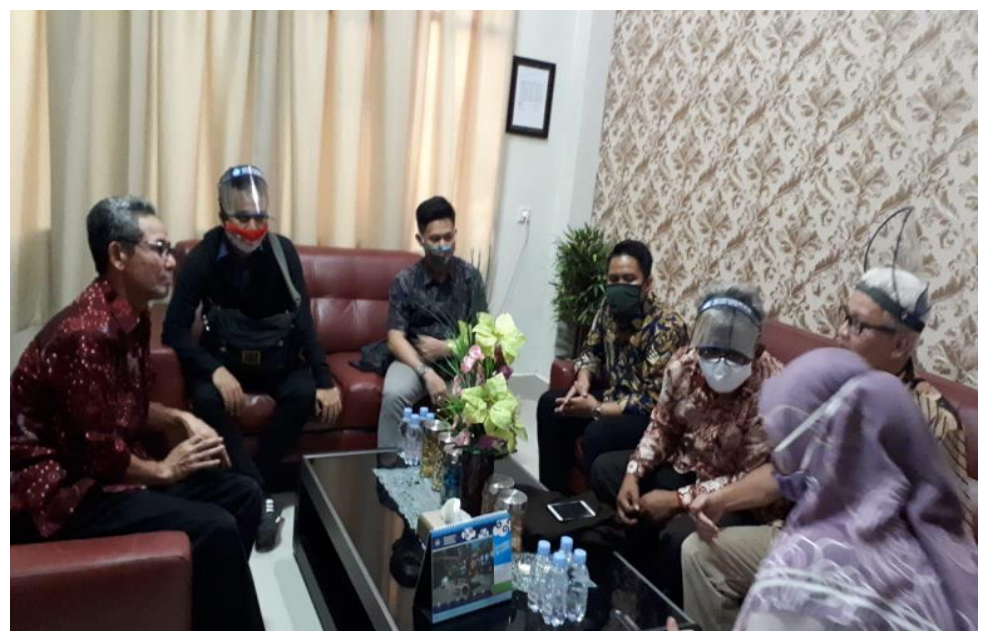

Gambar 2. Wawancara dengan Kepala dan Staf-staf BPPMPV Bidang KPTIK Gowa, Sulawesi Selatan

2. Pelaksanaan. Kegiatan pengabdian masyarakat ini dilakukan pada 10-11 September, dengan jumlah peserta sebanyak 30 orang. Metode sosialisasi dilakukan dengan menyampaikan paparan yang berisi poin-poin transformasi dari Permendikbud 26/2020 dan beberapa aspek revitalisasi strategis bagi BBPPMPV dan BPPMPV yang menjadi arahan Dirjen Pendidikan Vokasi.

3. Evaluasi. Tahapan ini dilakukan untuk mengetahui, sekaligus menganalisis tingkat efektivitas kegiatan pengabdian masyarakat. Oleh karena itu, disiapkan instrumen evaluasi untuk mengukur apakah terdapat peningkatan pemahaman kepada 40 orang peserta terkait arah reformasi BBPPMPV dan BPPMPV, khususnya di BPPMPV Bidang KPTIK di Kabupaten Gowa, Sulawesi Selatan. Hasil evaluasi tersebut menjadi penting untuk perbaikan di kemudian hari.

\section{Hasil dan Pembahasan}

Pada hari pertama, pelaksanaan kegiatan pengabdian masyarakat dimulai dari dilakukannya pre test untuk mengetahui tingkat pemahaman 30 peserta terhadap: 1) Kebijakan transformasi BPPMPV Bidang KPTIK Kabupaten Gowa, Sulawesi Selatan, yang tertuang dalam Permendikbud 26/2020 tentang Organisasi dan Tata Kerja Unit Pelaksana Teknis Kementerian Pendidikan dan Kebudayaan; dan 2) Kebijakan revitalisasi BPPMPV KPTIK Gowa, Sulawesi Selatan yang tertuang dalam aspek-aspek revitalisasi yang menjadi arahan Dirjen Pendidikan Vokasi, Kemendikbudristek. Hasil pre test dimaksud tertera pada diagram di bawah ini: 
[15] Abdul Rahman, dkk / To Maega: Jurnal Pengabdian Masyarakat, Vol.5; No.1; Februari, 2022

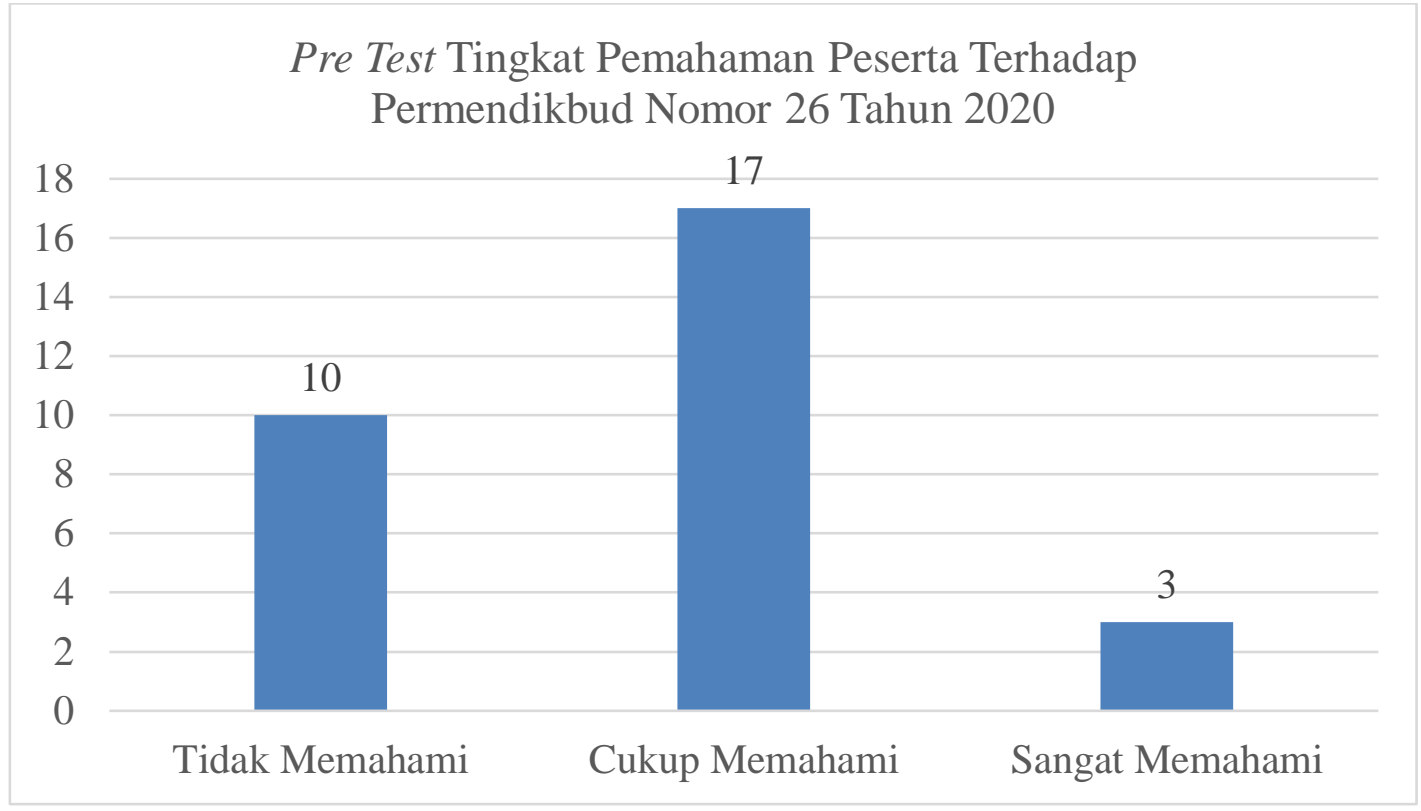

Diagram 1. Pre Test Tingkat Pemahaman Peserta Terhadap Permendikbud Nomor 26

Tahun 2020

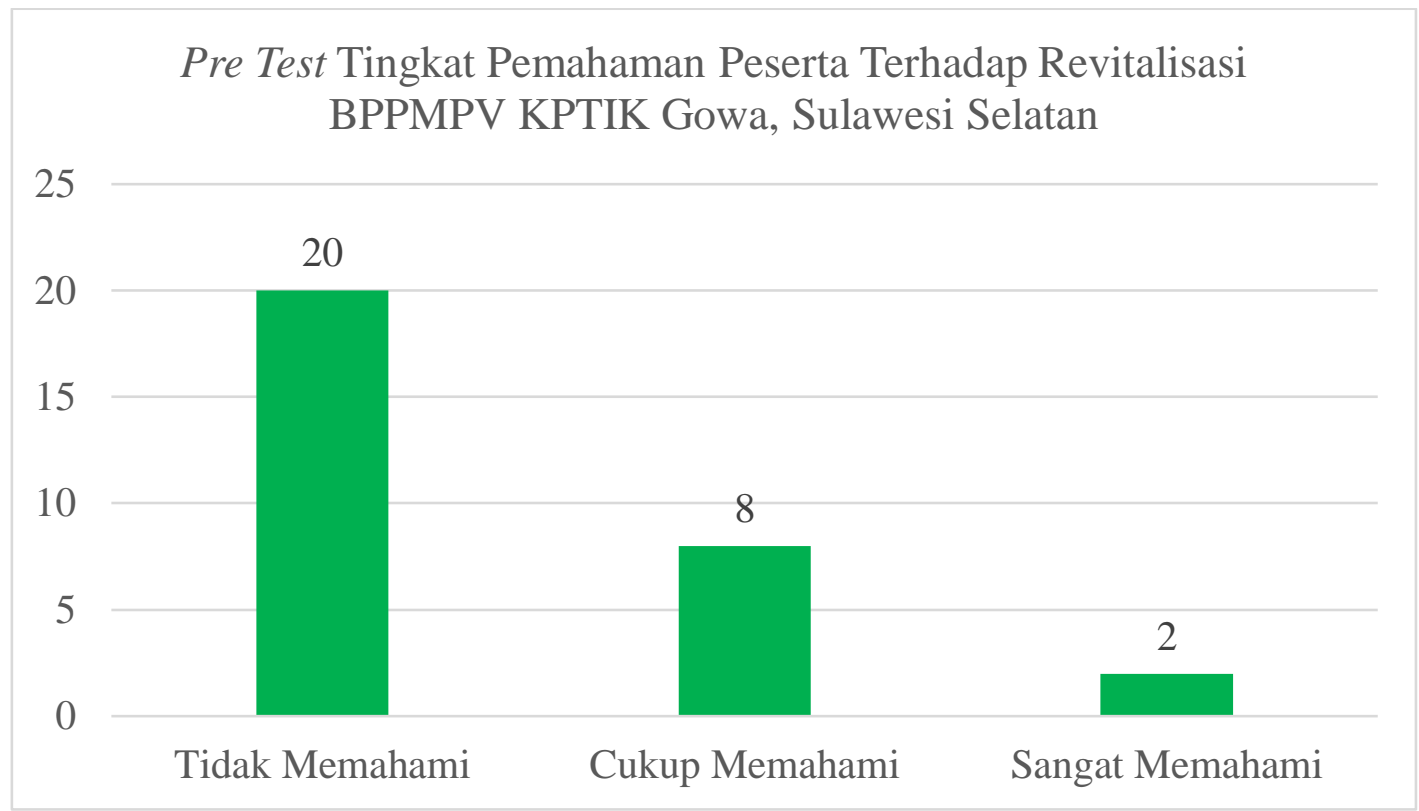

Diagram 2. Pre Test Tingkat Pemahaman Peserta Terhadap Revitalisasi BPPMPV KPTIK Gowa, Sulawesi Selatan

Dari kedua hasil pre test tersebut, dapat disimpulkan bahwa tingkat pemahaman peserta terhadap: 1) Permendikbud Nomor 26 Tahun 2020; dan 2) Revitalisasi BPPMPV KPTIK Gowa, Sulawesi Selatan masih relatif rendah. Pada pengukuran yang pertama, hanya 3 orang yang sangat memahami Permendikbud Nomor 26 Tahun 2020, sisanya 17 orang yang cukup memahami, dan terdapat 10 
orang yang tidak memahami. Sementara itu, pada pengukuran kedua, hanya 2 orang yang sangat memahami Revitalisasi BPPMPV KPTIK Gowa, Sulawesi Selatan, sisanya 8 orang yang cukup memahami, dan terdapat 20 orang yang tidak memahami.

Setelah dilakukan pre test, maka dilanjutkan dengan penyampaian materi sosialisasi Permendikbud 26/2020. Materi sosialisasi yang disampaikan ialah terkait dengan: Kedudukan, Tugas, Fungsi, Eselonisasi, dan Tata Kerja BPPMPV Bidang KPTIK Kabupaten Gowa, Sulawesi Selatan. Detail penyampaian materi sosialisasi tertera pada tabel di bawah ini:

Tabel 2. Materi Sosialisasi Kedudukan, Tugas, Fungsi, Eselonisasi, dan Tata Kerja BPPMPV KPTIK Gowa, Sulawesi Selatan

\begin{tabular}{lll}
\hline No. $\begin{array}{l}\text { Materi } \\
\text { Sosialisasi }\end{array}$ & Deskripsi Substansi \\
\hline & & Balai Pengembangan Penjaminan Mutu Pendidikan \\
& Vokasi Bidang Kelautan, Perikanan, Teknologi \\
& Informasi dan Komunikasi yang selanjutnya disebut \\
& BPPMPV KPTK, merupakan unit pelaksana teknis \\
& & Kementerian Pendidikan dan Kebudayaan di bidang \\
& pengembangan penjaminan mutu pendidikan vokasi \\
& Kedudukan & bidang kelautan, perikanan, teknologi informasi dan \\
& & komunikasi yang berada di bawah dan bertanggung \\
& & jawab kepada Direktur Jenderal Pendidikan Vokasi. \\
& & BPPMPV KPTK mempunyai tugas melaksanakan \\
& pengembangan penjaminan mutu pendidikan vokasi \\
& bidang kelautan, perikanan, teknologi informasi dan \\
& komunikasi
\end{tabular}

BPPMPV KPTK menyelenggarakan fungsi:

a. penyusunan program pengembangan penjaminan mutu

pendidikan vokasi bidang kelautan, perikanan, teknologi informasi dan komunikasi;

b. pelaksanaan penjaminan mutu peserta didik, sarana prasarana, dan tata kelola pendidikan vokasi

$3 \quad$ Fungsi bidang kelautan, perikanan, teknologi informasi dan komunikasi;

c. pelaksanaan penyelarasan pendidikan vokasi sesuai dengan kebutuhan dunia usaha dan dunia industri bidang kelautan, perikanan, teknologi informasi dan komunikasi;

d. pelaksanaan fasilitasi dan peningkatan kompetensi pendidik dan tenaga kependidikan pada 
pendidikan vokasi bidang kelautan, perikanan, teknologi informasi dan komunikasi;

e. pengelolaan data dan informasi;

f. pelaksanaan kerja sama di bidang pengembangan penjaminan mutu pendidikan vokasi bidang kelautan, perikanan, teknologi informasi dan komunikasi;

g. pelaksanaan evaluasi pengembangan penjaminan mutu pendidikan vokasi bidang kelautan, perikanan, teknologi informasi dan komunikasi; dan

h. pelaksanaan urusan administrasi

Kepala BPPMPV KPTK merupakan jabatan struktural

4 Eselonisasi eselon III. b atau sebutan lain sesuai dengan ketentuan peraturan perundang-undangan

- Dalam melaksanakan tugas dan fungsi, UPT berkoordinasi dengan: a. unit utama terkait; $b$. pemerintah provinsi; dan; c. pemerintah kabupaten/kota;

- Dalam melaksanakan tugas dan fungsi, UPT harus menyusun: a. peta bisnis proses yang menggambarkan tata hubungan kerja yang efektif dan efisien antar unit kerja; dan b. analisis jabatan, peta jabatan, analisis beban kerja, dan uraian tugas terhadap seluruh jabatan;

- Setiap unit kerja membantu Kepala UPT dalam melaksanakan tugas di bidang tugasnya masingmasing;

$5 \quad$ Tata Kerja

- Setiap pimpinan unit kerja dan kelompok jabatan fungsional dalam melaksanakan tugasnya wajib: a. menerapkan prinsip koordinasi, integrasi, dan sinkronisasi serta kerja sama yang baik di lingkungan internal maupun eksternal; $b$. melaksanakan akuntabilitas kinerja; dan c. melaporkan kegiatan yang menjadi tanggung jawabnya kepada atasan secara berjenjang;

- Setiap pimpinan unit kerja di lingkungan UPT bertanggung jawab memimpin dan mengoordinasikan bawahannya dan memberikan bimbingan serta petunjuk bagi pelaksanaan tugas bawahan; 
- Setiap pimpinan unit kerja wajib mengawasi bawahannya masing-masing dan apabila terjadi penyimpangan agar mengambil langkah-langkah yang diperlukan sesuai dengan ketentuan peraturan perundang-undangan;

- Setiap pimpinan unit kerja wajib mengikuti dan mematuhi petunjuk, bertanggung jawab kepada atasannya masing-masing dan menyampaikan laporan secara berkala tepat waktunya sesuai dengan ketentuan peraturan perundangundangan;

- Setiap laporan yang diterima oleh pimpinan unit kerja dari bawahan wajib diolah dan dipergunakan sebagai bahan penyusunan laporan lebih lanjut dan untuk memberikan petunjuk kepada bawahan;

- Dalam melaksanakan tugasnya setiap pimpinan unit kerja dibantu oleh kepala unit kerja di bawahnya dan dalam rangka pemberian bimbingan kepada bawahan masing-masing wajib mengadakan rapat berkala;

- Dalam melaksanakan tugas dan fungsi, Kepala UPT wajib menyampaikan laporan kepada unit pembina dengan tembusan kepada pimpinan unit organisasi yang secara fungsional mempunyai hubungan kerja dengan UPT.

Sementara itu, pada hari kedua materi sosialisasi yang disampaikan ialah terkait dengan beberapa aspek revitalisasi strategis bagi BPPMPV Bidang KPTIK Kabupaten Gowa, Sulawesi Selatan yang bersumber dari arahan Dirjen Pendidikan Vokasi, Kemendikbudristek. Revitalisasi dimaksud terdiri dari 4 aspek sebagai berikut:

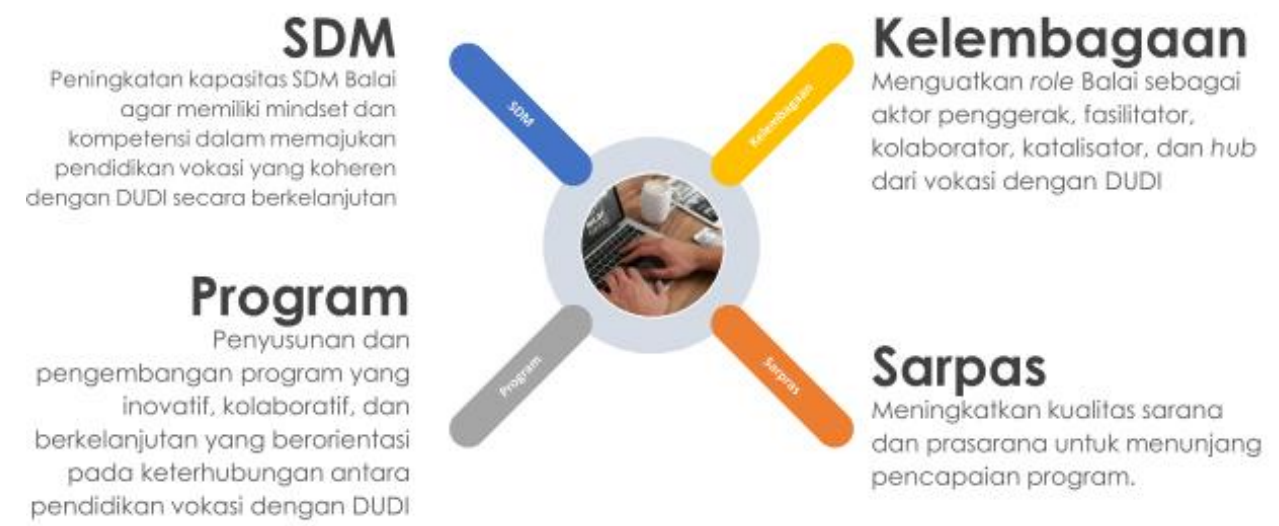

Gambar 3. Empat Aspek Revitalisasi BPPMPV KPTIK Gowa, Sulawesi Selatan 
1. Revitalisasi SDM. Obyektif utama dari aspek revitalisasi SDM ialah perubahan mindset SDM untuk keluar dari zona nyaman (out of the box), melalui internalisasi standar kompetensi dunia usaha dan dunia industri, memahami kebijakan dan program-program Direktorat Jenderal Pendidikan Vokasi, serta mengetahui teknik-teknik dan cara pendekatan ke dunia usaha dan dunia industri. Hal tersebut pada gilirannya diharapkan dapat membuat SDM-SDM di BPPMPV KPTIK Gowa, Sulawesi Selatan berkontribusi secara signifikan pada kemajuan pendidikan vokasi.

2. Revitalisasi Program. BPPMPV KPTIK Gowa, Sulawesi Selatan diharapkan dapat merumuskan, sekaligus mengimplementasikan program-program yang inovatif, kolaboratif, dan berkelanjutan yang berorientasi kepada link and match antara pendidikan vokasi dengan dunia usaha dan dunia industri. Program-program tersebut antara lain: 1) Peningkatan jumlah guru/instruktur/dosen yang mengikuti pelatihan upskilling dan reskilling berstandar dunia usaha, dunia industri, dan dunia kerja secara progresif; 2) Peningkatan pendampingan yang dilakukan oleh BPPMPV KPTIK dalam peningkatan mutu pendidikan vokasi; 3) Peningkatan peran BPPMPV sebagai think tank pengembangan pendidikan vokasi, baik dalam pengembangan kurikulum dan konsep praktek kerja berstandar dunia usaha dan dunia industri, serta dalam menerapkan teknologi revolusi industri 4.0.

3. Revitalisasi Kelembagaan. Arah reformasi dari aspek revitalisasi kelembagaan ialah BPPMPV KPTIK Gowa, Sulawesi Selatan diharapkan mampu bertransformasi secara progresif untuk menjembatani keterhubungan antara Pendidikan Tinggi Vokasi (PTV), Sekolah Menngah Kejuruan (SMK), dan Lembaga Kursus dan Pelatihan (LKP) dengan dunia usaha dan dunia industri, serta Kementerian/Lembaga/Pemerintah Daerah untuk mengembangkan ekosistem link and match yang berkelanjutan. Selain itu, BPPMPV KPTIK Gowa diharapkan dapat memberi alternatif-alternatif project konkrit strategis yang bisa dilakukan PTV, SMK, maupun LKP, administrasi kerjasama, dan komunikasi publik yang efektif dengan kemasan yang kekinian.

4. Revitalisasi Sarana dan Prasarana. Ketiga poin revitalisasi di atas, pada akhirnya juga perlu dilengkapi dengan ketersediaan sarana dan prasarana yang berkualitas, sehingga bisa mendukung tercapainya sasaran dari ketiga aspek revitalisasi yang ada. 

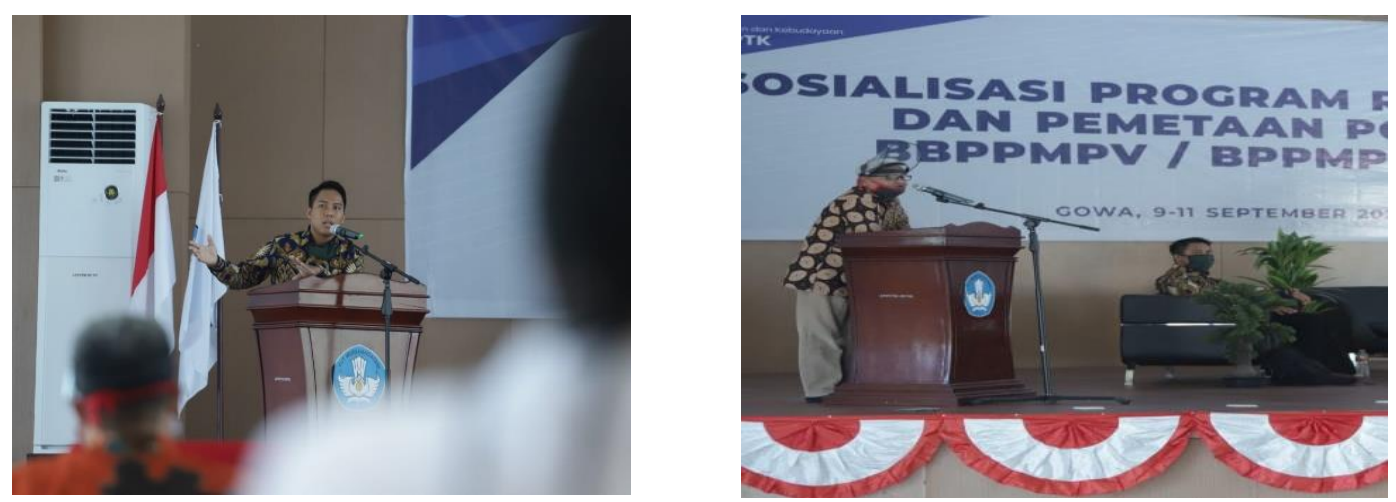

Gambar 4. Penyampaian Materi Sosialisasi Transformasi dan Revitalisasi BPPMPV KPTIK Gowa, Sulawesi Selatan

Setelah pemaparan materi sosialisasi kebijakan transformasi dan revitalisasi BPPMPV KPTIK Gowa Sulawesi Selatan selesai dilakukan, kegiatan pengabdian masyarakat dilanjutkan dengan sesi evaluasi untuk mengetahui signifikansi kegiatan kepada seluruh peserta. Evaluasi dilakukan dengan menggunakan post test untuk mengukur tingkat pemahaman materi sosialisasi dan tingkat kepuasan peserta terhadap pelaksanaan kegiatan. Pada evaluasi yang pertama, ditemukan hasil sebagaimana tertera pada diagram berikut.

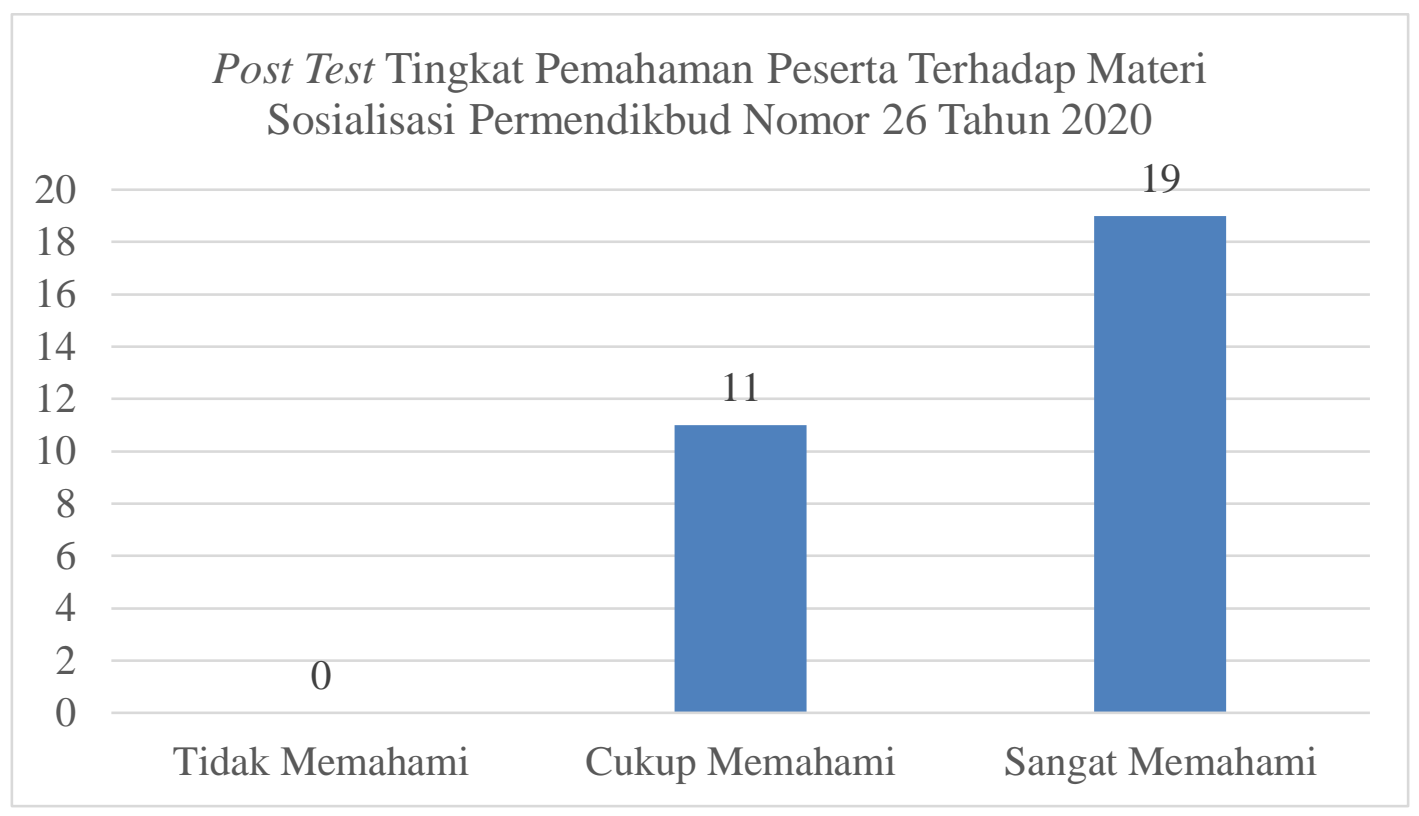

Diagram 3. Post Test Tingkat Pemahaman Peserta Terhadap Permendikbud Nomor 26 Tahun 2020 


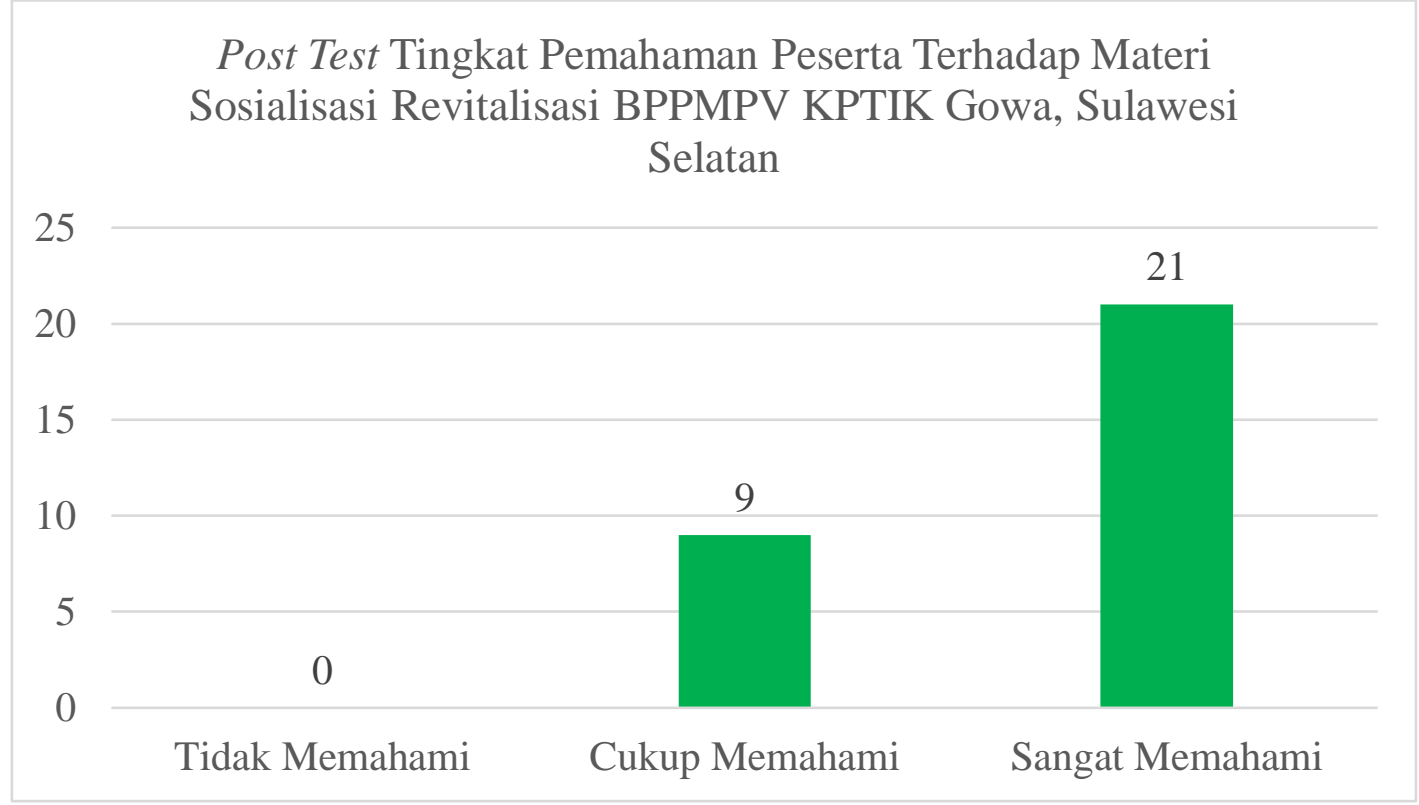

Diagram 4. Post Test Tingkat Pemahaman Peserta Terhadap Revitalisasi BPPMPV KPTIK Gowa, Sulawesi Selatan

Dari hasil post test yang tertera pada diagram 3, dapat dianalisis bahwa tingkat pemahaman 30 peserta meningkat cukup signifikan dibanding sebelumya (hasil pre test pada diagram 1). Bila di diagram 1 masih terdapat 10 peserta yang tidak memahami kebijakan transformasi BPPMPV KPTIK Gowa, Sulawesi Selatan yang tertuang pada Permendikbud 26/2020, di diagram 3 sudah tidak ada lagi yang tidak memahaminya. Selain itu, pada kategori sangat memahami juga terdapat peningkatan signifikan (19 peserta) dibanding sesi pre test pada diagram 1 (hanya 3 peserta yang sangat memahami).

Di sisi lain, hasil post test tingkat pemahaman peserta terhadap kebijakan revitalisasi BPPMPV KPTIK Gowa, Sulawesi Selatan yang tertera pada diagram 4 mengindikasikan peningkatan pemahaman yang juga relatif signifikan, dibanding sebelumya (hasil pre test pada diagram 2). Bila di diagram 2 masih terdapat 20 peserta yang tidak memahami kebijakan revitalisasi BPPMPV KPTIK Gowa, Sulawesi Selatan yang bersumber dari arahan strategis Dirjen Pendidikan Vokasi, Kemendikbudristek, pada diagram 4 sudah tidak ada lagi yang tidak memahaminya. Selain itu, pada kategori sangat memahami juga terdapat peningkatan signifikan (21 peserta) dibanding sesi pre test pada diagram 2 (hanya 2 peserta yang sangat memahami).

Peningkatan pemahaman terhadap 2 kebijakan tersebut mengindikasikan efektivitas penyampaian materi sosialisasi dalam format pengabdian masyarakat. Sementara itu, kegiatan pengabdian masyarakat ini juga mengukur tingkat kepuasan peserta terhadap pelaksanaan kegiatan, karena merupakan bagian yang tidak terpisahkan dalam aspek evaluasi. Dari total 30 peserta, terdapat sebanyak 23 
peserta $(77 \%)$ yang puas dengan pelaksanaan kegiatan pengabdian masyarakat 5 peserta (17\%) yang merasa cukup puas, dan 2 peserta (6\%) yang tidak puas.

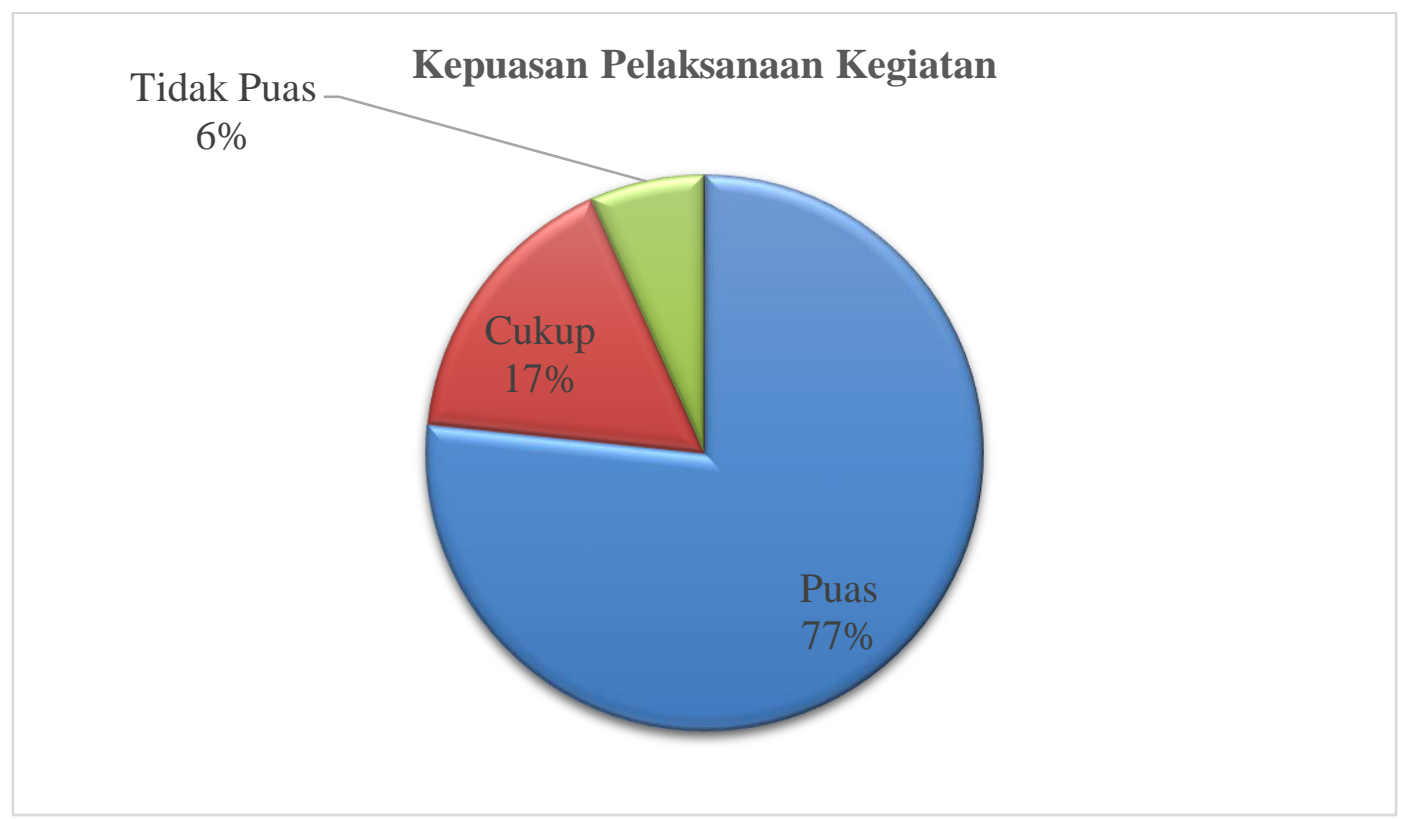

Diagram 5. Tingkat Kepuasan Peserta Terhadap Pelaksanaan Kegiatan Pengabdian Masyarakat

\section{Kesimpulan}

Berdasarkan uraian-uraian yang didekripsikan, mulai dari pendahuluan hingga hasil dan pembahasan, dapat disimpulkan bahwa pelaksanaan sosialisasi kebijakan transformasi dan revitalisasi Balai Pengembangan Penjaminan Mutu Pendidikan Vokasi (BPPMPV) Bidang Kelautan, Perikanan, Teknologi Informasi dan Komunikasi (KPTIK) di Kabupaten Gowa, Sulawesi Selatan efektif. Justifikasi tersebut merujuk kepada adanya peningkatan secara signifikan pemahaman peserta terhadap kedua jenis kebijakan tersebut, dan tingkat kepuasan peserta terhadap pelaksanaan kegiatan pengabdian masyarakat.

\section{Daftar Pustaka}

Agrawal, T., \& Agrawal, A. (2017). Vocational education and training in India: a labour market perspective. Journal of Vocational Education and Training, 69(2), 246-265. https://doi.org/10.1080/13636820.2017.1303785

Billett, S. (2016). Beyond competence: an essay on a process approach to organising and enacting vocational education. International Journal of Training Research, 14(3), 197-214. https://doi.org/10.1080/14480220.2016.1254365

Dharta, F. Y., Kusumaningrum, R., \& Chaerudin, C. (2021). Penguatan Strategi Komunikasi Pada Pengelola Destinasi Wisata Di Kabupaten Karawang. To Maega: Jurnal Pengabdian Masyarakat, 4(2), 133-144.

Hodge, S., Atkins, L., \& Simons, M. (2016). Towards an Epistemically Neutral 
[23 ] Abdul Rahman, dkk/To Maega: Jurnal Pengabdian Masyarakat, Vol.5; No.1; Februari, 2022

Curriculum Model for Vocational Education: From Competencies to Threshold Concepts and Practices. International Journal of Training Research, 14(3), 1-16.

Jones, A. (2018). Vocational Education for the Twenty First Century. Melbourne: LH Martin Institute, University of Melbourne, 11(August), 21-43. https://doi.org/10.1007/978-3-030-52229-2_3

Kemdikbud RI. (2020). Permendikbud Nomor 26 Tahun 2020. Http://Kemdikbud.Go.Id/. Retrieved from http://kemdikbud.go.id/main/?lang=id

Nugroho, R. (2017). Kebijakan Publik (6th ed.). Jakarta: Elex Media Komputindo.

Peraturan Pemerintah Republik Indonesia. Peraturan Pemerintah Republik Indonesia Nomor 57 Tentang Standar Nasional Pendidikan., Standar Nasional Pendidikan $\S(2021)$.

Pilz, M. (2017). Vocational Education and Training in Times of Economic Crisis: Lessons from Around the World. In Technical and Vocational Education and Training: Issues, Concerns and Prospects (1st ed., Vol. 24). https://doi.org/10.1007/978-3-319-47856-2_11

Rahman, A., Mawar, Wahyuning Dyas Tuti, R., Handayani, N., \& Sahrul, M. (2021). Key Determinants of Elementary School Education Policy Implementation in Border Region. Jurnal Ilmiah Ilmu Administrasi Publik, 11(1), 111. https://doi.org/10.26858/jiap.v11i1.20585

Tahir, A. (2014). Kebijakan publik dan transparansi penyelenggaraan pemerintahan daerah. Penerbit Alfabeta.

Undang-undang Nomor 20 Tahun 2003 Tentang Sistem Pendidikan Nasional. , Pub. L. No. 20 (2003).

Widodo, S., \& Wardani, R. K. (2020). Mengajarkan Keterampilan Abad 21 4C (Communication, Collaboration, Critical Thinking and Problem Solving, Creativity and Innovation) di Sekolah Dasar. MODELING: Jurnal Program Studi PGMI, 7(2), 185-197. 